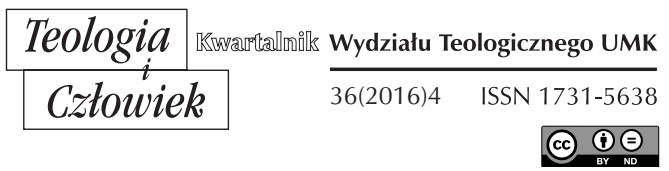

MARIUSZ FINKIELSZTEIN*

WARSZAWA

\title{
PROJEKT WSPÓLNOTY CHRZEŚCIJAŃSKIEJ W KOBIERCACH KLEMENSA ALEKSANDRYJSKIEGO
}

DOI: http://dx.doi.org/10.12775/TiCz.2016.051

Klemens Aleksandryjski (ok. 150-ok. 215) był jednym z pierwszych ojców Kościoła, teologiem wczesnochrześcijańskim, postacią z pewnością nietuzinkową, chociaż mało znaną poza kręgiem specjalistów. W pamięci potomnych często był przyćmiewany przez swojego, wzbudzającego wiele kontrowersji ucznia, Orygenesa. Klemens jest autorem głównie dzieł dydaktycznych, z których największe znaczenie ma trylogia wychowawcza

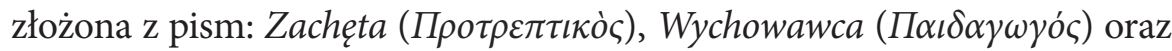
Kobierce $(\Sigma \tau \rho \omega ́ \mu \alpha \tau \alpha)$. Kolejne jej części odnoszą się do następujących po sobie etapów dochodzenia do świętości. Są nimi kolejno: nawrócenie, wychowanie oraz nauczanie, mające na celu pogłębienie cnót i ostateczne ukształtowanie jednostki jako świadomego chrześcijanina. Temu ostatniemu etapowi miało właśnie odpowiadać dzieło, będące główną inspiracją

* Mgr Mariusz Finkielsztein - doktorant w Instytucie Socjologii Uniwersytetu Warszawskiego. Pracuje nad rozprawą doktorską, dotyczącą zjawiska nudy w środowisku uniwersyteckim. Jego zainteresowania badawcze obejmują przede wszystkim nudę w ujęciu interdyscyplinarnym i historycznym (w tym zjawisko acedii) oraz wczesnochrześcijańską myśl społeczną (mariusz.finkielsztein@gmail.com). 
dla tej pracy, czyli Kobierce, których pełny tytuł brzmi Kobierce zapisków gnostycznych wedtug prawdziwej filozofii ${ }^{1}$. Jest ono zbiorem niesystematycznych i często niekonsekwentnych zapisków na różnorodne tematy, dotyczące bycia chrześcijaninem i chrześcijaństwa w ogólności. Dzieło to zgodnie z logiką trzech etapów rozwoju powinno nazywać się Nauczyciel $(\Delta \iota \delta \alpha \dot{\alpha} \sigma \alpha \lambda \circ \varsigma)$, jednak Klemens odrzucił ten tytuł. Mając na uwadze brak tej konsekwencji oraz mało staranną strukturę dzieła, badacze suponowali, iż „Kobierce” mogły stanowić „zbiór zapisków, notatek czy materiałów, które Klemens zamierzał wykorzystać przy ostatecznej redakcji przyszłego Didaskalosa"2.

Klemens jako człowiek wykształcony ubolewał nad niskim poziomem intelektualnym chrześcijaństwa i chrześcijan swoich czasów. W Kobiercach często posiłkuje się pismami pogańskimi, przede wszystkim dziełami filozofów (m.in. stoików, Platona, Arystotelesa i Epikura), jak również poetów i dramatopisarzy. Filozofia jest wedle jego koncepcji (zresztą zapożyczonej od Filona z Aleksandrii) plagiatem Starego Testamentu i jako taka jest darem danym przez Boga Grekom. Jest ona nauczycielem, pewnym substytutem nauk Chrystusa, surogatem zbawienia, dzięki naczelnej zasadzie ją konstytuującej, czyli Logosowi. Polemizuje on tym samym z tymi spośród chrześcijan, którzy w filozofii widzieli dzieło diabła i uważali, że „Bóg wybrał właśnie to, co głupie w oczach świata, aby zawstydzić mędrców" (1 Kor 1,27). Chciał pokazać zarówno poganom, krytykującym chrześcijaństwo za jego antyintelektualizm, jak i wątpiącym, wykształconym i skłaniającym się ku gnozie chrześcijanom, iż wiarę da się połączyć z wiedzą i dążeniem do mądrości oraz, co za tym idzie, że ideał chrześcijańskiego filozofa jest nie tylko możliwy, ale również pożądany.

Kobierce stanowią pewnego rodzaju przewodnik po chrześcijaństwie dla ludzi wykształconych (tzn. znających dzieła autorów klasycznych). Miało ono im pomóc w stworzeniu spójnej narracji tożsamościowej oraz ustrzec przed błędami szerzącego się w owym czasie gnostycyzmu. Klemens wypowiada się w Kobiercach na tematy zarówno doktrynalne,

${ }^{1}$ Dla potrzeb pracy korzystałem z wydania: Klemens Aleksandryjski, Kobierce, tłum. J. Niemirska-Pliszczyńska, I-II, Warszawa 1994; dalej oznaczane tylko liczbą rzymską, określającą numer kobierca i arabską, podającą adres szczegółowy fragmentu.

2 F. Drączkowski, Kościót-Agape według Klemensa Aleksandryjskiego, Lublin 1996, s. 45. 
jak również głęboko praktyczne, takie jak małżeństwo, męczeństwo, cechy idealnego chrześcijanina, wartości budujące chrześcijańską tożsamość itp. W swym erudycyjnym dziele jest Klemens wielkim obrońcą ciała ${ }^{3}$ i małżeństwa (po nim nastąpi eskalacja postaw propagujących ascetyzm cielesny i dziewictwo), zaleca afirmację stworzenia, która staje się ważnym krokiem na drodze do zbawienia ${ }^{4}$. Zabiera również głos $\mathrm{w}$ kwestii poruszonej przez św. Pawła, dotyczącej kryteriów uznania kogoś za chrześcijanina, powołując do życia kategorię „chrześcijan z imienia” (IV 17,1-4). Jego praca wpisywała się w rodzący się nurt chrześcijańskiego pisarstwa, próbujący zintelektualizować religię chrystusową i pogodzić ją ze światem zastanym (Tertulian, Klemens Rzymski i in.). Rezultaty tych dociekań do dziś widoczne są w nauczaniu i retoryce Kościoła.

W pracy chciałbym pokazać społeczne implikacje myśli Klemensa - zrekonstruować jego wizję wspólnoty chrześcijańskiej. W swoim dziele skupia się on na jednostkowych manifestacjach postawy chrześcijańskiej. Jednak jak będę starał się udowodnić, to wspólnota jest tym, co w istocie stanowi cel konstrukcji Klemensa. Tworzy on w miarę spójny, chociaż chaotycznie wyrażony ${ }^{5}$ projekt społeczności chrześcijańskiej, w którym jednak silnie rysuje się kwestia relacji między jednostką, szczególnie tą wybitną, a wspólnotą. Wydaje się, iż nie ma odpowiedzi, który z tych dwóch elementów jest ważniejszy. Niejasny wydaje się również stosunek obu podmiotów do siebie nawzajem. Czy i jak wybijająca się jednostka ma wpływać na społeczność, jaki ma mieć do niej stosunek, czy ma ona

${ }^{3}$ „Ani dusza nie jest $\mathrm{z}$ natury dobra, ani ciało z natury złe, człowiek „składa się wprawdzie z części odmiennych, ale bynajmniej nie przeciwstawnych, to jest $\mathrm{z}$ ciała i duszy” (IV 164,5) albo „W jakiż zaś sposób bez pośrednictwa ciała plan Boży Kościoła naszego mógłby się realizować” (III 103,3).

4 „Kto siebie kocha, kocha i pana, oraz przyznaje się do swego Zbawiciela, aby ocalić duszę" (IV 42,5).

${ }^{5}$ Jak określił to, tyle żartobliwie, co trafnie, poważny badacz starożytnego chrześcijaństwa, Henry Chadwick, „niekiedy odnosi się wrażenie, że Klemens jest wręcz zatroskany, aby nic nie było zbyt jasne" (H. Chadwick, Myśl wczesnochrześcijańska a tradycja klasyczna, tłum. P. Siejkowski, Poznań 2000, s. 41). Ma się wrażenie, iż w Kobiercach niemal wszystko łączy się ze wszystkim i wszystko ze wszystkiego wynika, dając odmienne wnioski w różnych miejscach. Klemens swobodnie dryfuje po tematach, powraca z niezbadaną regularnością do pewnych wątków, aby powiedzieć coś inaczej czy uszczegółowić pewne kwestie, zmieniając ich zabarwienie. 
monopol na pewność zbawienia? Kwestie te wydają się aktualne przez całą historię chrześcijaństwa (gnostycyzm, koncyliaryzm, kwestia publicznej jednostkowej pobożności, święci). Trudno rozpatrywać jedno bez drugiego. Klemens uznaje wybitną jednostkę (gnostyka ${ }^{6}$ ) za wzór osobowy dla całej wspólnoty, która powinna dążyć do upodobnienia się do niego we wszystkich swoich tkankach. Należy zatem zacząć od krótkiego opisu wizji idealnego chrześcijanina.

\section{OSOBOWY WZÓR CHRZEŚCIJANINA}

Podstawowymi pożądanymi atrybutami chrześcijanina są cnoty. Główną zasadą kierującą ich relacjami jest zasada koegzystencji. Cnoty według Klemensa „występują złączone ze sobą w jeden nierozerwalny łańcuch” (II 80,2), pozostają ze sobą we wzajemnym związku, tworząc silne relacje wynikania. Podstawowymi cnotami według niego są wiara, bojaźń boża oraz Prawo. Wiarę nazywa Klemens „matką cnót”, „dobrowolną akceptacją wstępną" (II 8,4) umysłowej jedności z niepoznawalnym, oraz „pierwszą przemianą zbawczą" (VII 57,4). W jego wizji stanowi ona pierwsze, niezbędne ogniwo $\mathrm{w}$ łańcuchu oraz wstępny krok na drodze prowadzącej do prawdy i zbawienia ${ }^{8}$.

Bojaźń boża jest drugim krokiem na drodze do zbawienia. Strach przed Bogiem nie jest czymś pierwotnym jak strach przed śmiercią, ale wynika ze stosunku zależności. Bóg jest zwierzchnikiem, którego Prawom lękamy się przeciwstawić i Ojcem, którego boimy się zawieść. Nasze uczucia $\mathrm{w}$ stosunku do niego są rodzajem timor reverentialis, strachu pełnego

${ }^{6}$ Klemens redefiniuje to pojęcie, odrywając je od gnostycyzmu i nadając mu ogólniejsze znaczenie, męża który posiadł wiedzę ( $\gamma v \omega ́ \sigma \iota \varsigma)$, w której zawiera się również element wiary. Gnostyk Klemensa nie jest tym, który odebrał nauki jakiejś szkoły gnostyckiej, ale tym który zbliżył się do Boga dzięki wierze i kultywowaniu cnót.

7 Zasada ta po raz pierwszy pojawiła się w myśli stoickiej i dotyczy współzależności i równoczesnego współistnienia wszystkich wartości moralnych, zob. Diogenes Laertios, Żywoty i poglądy słynnych filozofów, tłum. I. Krońska, Warszawa 2004, VII 125.

${ }^{8}$ Klemens tworzy różne warianty łańcuchów cnót, które nigdy nie tworzą w pełni koherentnej koncepcji, jednak zawsze na ich początku stoi wiara, np. „wiara daje początek, bojaźń Boża ( $\varphi$ óßoৎ) buduje, a doskonali wszystko agape” (II 54,4). 
szacunku, który ściśle związany jest $\mathrm{z}$ przestrzeganiem ustalonych $\mathrm{w}$ tej relacji zasad (zob. II 53,4). Stosunek do Boga łączy w sobie bliskość i dystans, miłość i strach, będący w gruncie rzeczy lękiem przed odpadnięciem od Boga (czyli od Dobra), utratą jego łaski (korzyści z partycypacji w jego wspólnocie wartości).

Ważnym elementem konstytuującym wzory zachowań i postaw chrześcijanina jest Prawo, którego przestrzeganie jest cnotą równą dwóm wcześniej omówionym. Pokazuje ono kierunek dalszego doskonalenia oraz stanowi pomoc i zachętę "do przypomnienia sobie prawdy i do jasnego jej wyrażenia” (IV 4,4). Razem z bojaźnią bożą prowadzi do mądrości, panowania nad sobą i miłości".

Wymienione cnoty mają, według Klemensa, doprowadzić jednostkę do gnozy, która jest „rodzajem doskonalenia się człowieka jako człowieka, osiągalnym poprzez wiedzę o sprawach boskich w relacji do sposobu myślenia, trybu życia i wypowiedzi” (VII 55,1). Jest ona „pewnym i niewątpliwym dowodem założeń przyjętych przez wiarę" i w połączeniu $\mathrm{z}$ tym fundamentem poznania „prowadzi nas do przekonania niemożliwego już do obalenia i opartego na naukowej pewności” (VII 57,3). Ideałem jednak i najwyższą wartością jest gnostyczna agape.

\section{GNOSTYK - CHRZEŚCIJANIN WZORCOWY}

Podstawową cechą postawy gnostyckiej, będącą również kluczową cechą chrześcijanina w ogóle, jest dobrowolność i świadomość. Wejście na drogę nauk Chrystusa nie może być motywowane pragnieniem nagrody lub chęcią uniknięcia kary a jedynie wolą poznania Boga, intencją uczestniczenia w jego nieprzemijalności. Gnostyk chce poznania najwyższego Dobra dla niego samego i czyni dobrze po to, aby osiągnąć piękno moralne $e^{10}$.

9 J 5,3: „albowiem miłość względem Boga polega na spełnianiu Jego przykazań”. (wszystkie cytaty z Biblii za: Pismo Święte Starego i Nowego Testamentu w przekładzie z języków oryginalnych. [Biblia Tysiąclecia], Pallottinum 1998.

${ }^{10}$ Por. Arystoteles, Etyka wielka I, 19: „Celem ostatecznym doskonałości jest piękno moralne". 
Jeśliby więc, załóżmy tylko, zaproponował ktoś gnostykowi, czy wolałby wybrać poznanie Boga czy zbawienie wieczne i gdyby to było rozdzielone (aczkolwiek ponad wszelką wątpliwość jest to bytowa tożsamość), to bez jednej chwili zwłoki gnostyk wybrałby poznanie Boga w tym głębokim przeświadczeniu, że godna jest wyboru ze względu na samą siebie szczególna odrębność drogi gnostycznej, wiodącej ponad wiarą poprzez miłość do poznania. (IV 136,5)

Droga gnostycka jest więc ciągłym dążeniem do cnót i, poprzez nie, do poznania. „Nie jest w ogóle możliwe, aby mężczyzna czy kobieta doszli w jakiejkolwiek dziedzinie do sławy bez uprzedniego kształcenia, ćwiczenia i praktykowania. A nawet twierdzimy, że uzyskanie cnoty nie zależy od niczego innego, jak wyłącznie od nas samych" (IV 124,1-3, por. II 69,2). Tym samym zgadza się ze stoikami, twierdząc, iż cnota jest czymś czego można się wyuczyć i czego ćwiczenie i doskonalenie jest wolicjonalne.

Zasadniczo, wszyscy mają równe szanse doskonalenia cnót i zbawienia, a to za przyczyną tożsamości natury u wszystkich ludzi, która skłonna jest zarówno do grzechu, jak i do kultywowania cnót ${ }^{11}$. Gnostykiem można zatem zostać niezależnie od wieku czy płci. Niezależne jest to również od wykształcenia jednostki. Jak pisze Klemens: „wolno jest bowiem każdemu żyjącemu w naszej wspólnocie dążyć do mądrości, nawet bez wykształcenia" (IV 58,3). W innym miejscu twierdzi jednak, iż „pierwszym szczeblem zbawienia jest wykształcenie” (IV 53,1). Wydaje się, iż te rozbieżności wyjaśnić można względami retorycznymi - Klemens dostosowuje swoje tezy do partykularnego celu danego ustępu. Wydaje się jednak, iż wykształcenie niezbędne jest dla zbawienia na drodze gnostyckiej. Autor Kobierców wymienia pięć możliwych dróg prowadzących do zbawienia. Są to: droga pobożnego, wstrzemięźliwego, pracowitego, męczennika oraz gnostyka. Ta ostatnia jest najbardziej zalecaną, lecz nie przeznaczoną dla wszystkich, gdyż łącząc w sobie wszystkie pozostałe drogi ${ }^{12}$, wymaga największego wysiłku woli. Każdy powinien dążyć do

${ }^{11}$ Klemens idzie w tym tak daleko, iż rozciąga pojęcie natury ludzkiej nawet na barbarzyńców (IV, 8), co było rzadko spotykane w jego czasach.

${ }_{12}$ Pierwsze dwie drogi ścieżka gnostycka zawiera ex definitione, trzecią implikuje z powodu pojemności pojęcia „praca”, a z męczeńską łączy się w godzinie próby, na którą gnostyk musi być zawsze przygotowany. 
doskonałości na drodze, do której został powołany, gdyż tylko nią może dojść do zbawienia.

Esencją drogi gnostyckiej jest kultywowanie cnót, dla których podstawą stoicka zasada apathei, mówiąca o stłumieniu wszystkich nierozumnych pragnień, które przeszkadzają w szczęściu, odwodząc od rzeczy prawdziwie wartych poznania ${ }^{13}$. Bezafektywność jest celem wszystkich dążeń gnostyka, czego efektem powinna być doskonała identyfikacja, „bycie samą wiedzą i samym poznaniem” (IV 40,1). Gnostyk nie jest jednak pełnym wcieleniem ideału moralnego, gdyż żaden z ludzi nie może za swojego życia osiągnąć „doskonałości pod każdym względem” (IV 130,2) ${ }^{14}$. Klemens w swych poglądach na gnostycką bezafektywność jest do tego stopnia radykalny, iż odrzuca koncepcję eupathei umiarkowanych stoików i twierdzi, iż gnostyk nie powinien mieć do czynienia $\mathrm{z}$ żadnymi stanami emocjonalnymi, gdyż $\mathrm{w}$ ich zbiorze nie ma takich, które można oceniać pozytywnie (VI 74,2; VI 72,2-73,1). Stąd również jego pogląd na istotę agape, której nie tylko nie uznaje za afekt, ale wyróżnia jako zastępującą wszystkie afekty (VI 71,4).

Celem tych wszystkich zabiegów jest upodobnienie się do Boga (zob. m.in. II 103,1). Gnostyk powinien pozostawać w „zbawiennej dyspozycji”, to znaczy „zachowywać rozum w stanie pełnej i niezmiennej jakości” (II 139,4). Z tego powodu nie będzie on pragnął przyziemnej sławy ani starał się uzyskać zewnętrznej pomyślności, „lecz będzie uzależniał od swego wnętrza uzyskanie szczęścia i zadowolenia z królewskiej przyjaźni z Bogiem” (IV 52,2). Gnostyk jest przyjacielem Boga i jego sługą jednocześnie.

\section{GNOSTYK - PRZYJACIEL BOGA}

Klemens porównuje relację gnostyka z Bogiem do powrotu do idealnej harmonii człowieka ze Stwórcą, będącej jego udziałem w ogrodzie Eden. Wyraża to pisząc, że gnostycy „zostaną przywróceni do stanu

${ }^{13}$ Tu Klemens wymienia cztery, które są powodem wszystkich innych, tj. miłość do kobiet, sławy, władzy oraz rzeczy materialnych (chciwość).

${ }^{14}$ Wyjątek stanowili apostołowie, poprzez swój osobisty stosunek z Jezusem i napełnienie Duchem. 
upragnionego synostwa Bożego" (IV 40,3; por. VI 75,2) Określenie ogrodu posłużyło Klemensowi do zbudowania roślinnej metafory, w której człowiek-roślina musi być „przesadzony” ze starego życia do gleby prawdy, "posadzony w Chrystusie" (to znaczy przeniesiony w nowe otoczenie cnót i odpowiadających im wartości) z dala od dawnej drogi życia (zob. VII 27). W takiej tylko glebie gnostyk może się rozwinąć i upodobnić do Boga. Pozycję gnostyka wobec Boga w sposób klarowny tłumaczy Klemens wyodrębniając trzy stopnie wtajemniczenia. $Z$ początku, tuż po nawróceniu chrześcijanin jest tylko sługą ( $\delta o v ́ \lambda o \varsigma)$, niewolnikiem grzechów. Z czasem poznaje nauki chrześcijańskie, staje się wiernym sługą ( $\pi \iota \sigma \tau o ́ \varsigma)$. Gdy zbliża się do doskonałości, staje się przyjacielem Boga ( $\varphi$ ì $о \varsigma)$, który ma udział w jego tajemnicach. Ewolucyjny charakter chrześcijańskiej postawy dobrze ilustrują słowa $\mathrm{z}$ ewangelii św. Jana, wypowiedziane przez Jezusa, mówiące o tym, iż jest on drogą, prawdą i życiem (J 14,6). Tym trzem orzecznikom łatwo przypisać trzy Klemensowskie stadia „rozwojowe" chrześcijanina. Najpierw wyrusza on w drogę, poznając nauki Jezusa, następnie dochodzi dzięki nim do poznania, aby w końcu wdrożyć jego efekty w działania. Sprzeciwiał się on tym samym doktrynom gnostyków, którzy „twierdzili, że mogą, poprzez momentalne „odkupienie”, ominąć wymagane od każdego chrześcijanina długie przygotowanie moralne i intelektualne"15 (Brown 2006: 141).

\section{GNOSTYK - WCIELONA AGAPE}

Gnostyk poprzez boską agape „jest zadomowiony w Bogu” (VI $102,1)$ i całkowicie na niego ukierunkowany (VI 71,4). Poprzez to ustawia swe życie na tej samej częstotliwości, co rytm życia bożego. Wychodzi z platońskiej jaskini, jest w stanie oglądać Idee, staje się podobny stoickiemu mędrcowi, który dochodzi do stanu równości z bogami, staje się ich sprzymierzeńcem. Klemens objaśnia objawienie zawarte w koncepcji pogańskiej pisząc, iż „rozum jest siedzibą idei, rozumem jest Bóg (por. $\mathrm{J}$ 1,1). Tego więc, „kto potrafi oglądać Boga niewidzialnego, nazwał Platon żyjącym wśród ludzi bogiem” (IV,24; 155,2; por. Platon, Sofista 210 B-C)

15 P. Brown, Ciało i społeczeństwo, tłum. I. Kania, Kraków 2006, s. 141. 
Z tych faktów wysnuwa Klemens praktyczne wnioski, pisząc, iż „bliski związek ze sprawami ducha odsuwa gnostyka w sposób naturalny od świata zmysłów" (IV 148,1). Gnostyk bliski jest Bogu przez agape, która stanowi „więź (węzeł) doskonałości” (Kol 3,14). Jak pisze Franciszek Drączkowski:

Gdyby pozostać przy metaforze, według której cnoty miały być jakoby poszczególnymi szatami czy częściami garderoby to agape nie byłaby jedną z wielu „sukienek”, lecz „przepasaniem”, ”przewiązaniem”, „upięciem szat", pasem, który wszystko spina i razem wiąże, czymś, dzięki czemu strój stawał się „całkowity i zupełny ${ }^{16}$.

Agape jawi się więc jako apogeum cnót, jako element nadający kształt całości, ale również jako cnota, która kieruje wszystkie inne ku określonemu celowi, będąc funkcjonalnym łącznikiem między gnostykiem a „Najwyższą Doskonałością".

Jednak to wszystko nie neguje partycypacji gnostyka we wspólnocie ziemskiej. Chociaż świadomie oddala się on od ludzi, by być bliżej Boga, to jednak ,trwając w egzystencji nadprzyrodzonej i przyrodzonej jest szczęśliwy i radosny dzięki agape, która dynamizując go i uzdalniając do dobrego działania na terenie rzeczywistości ziemskiej równocześnie go jednoczy ze wspólnotą życia Bożego, dając mu już obecnie uczestnictwo w szczęściu życia przyszłego" ${ }^{17}$. Spełnienie w relacji z Bogiem daje mu siły i motywację do aktywności na ziemi, która według Klemensa polega na byciu przeciętnym członkiem wspólnoty, mężem i ojcem rodziny:

prawdziwym mężczyzną ukazuje się (gnostyk -MF) nie przez wybór dla siebie życia samotnego, lecz tym zwycięża mężów, iż troszcząc się o małżeństwo, płodzenie dzieci oraz opiekę nad domem jednocześnie nie wykazuje wrażliwości ani na rozkosz, ani na ból. Mimo kłopotów o dom, nie daje się oderwać od miłości do Boga, zwycięsko wychodząc z wszelkiej próby, na jaką tylko wystawia go sytuacja ojca rodziny, męża, pana służby i właściciela majątku (VII 70,78).

${ }^{16}$ F. Drączkowski, Kościół , s. 66.

17 Tamże, s. 115.

${ }^{18}$ Por. P. Brown, Ciało s. 142. 
Gnostyk, dzięki boskiej agape, „łączy w sobie ideał życia wewnętrznego z życiem praktycznym" ${ }^{19}$. Nie jest on niezrozumianym mędrcem, ale starszym, bardziej doświadczonym członkiem wspólnoty - stanowi on niejako jej kwintesencję.

\section{WIZJA WSPÓLNOTY CHRZEŚCIJAŃSKIEJ}

Wspólnota nie jest zbiorem poszczególnych jednostek, nie jest prostą sumą swoich części składowych. Chrześcijaństwo miało taką siłę i prężnie rozwijało się, pomimo wielu przeciwności, właśnie dzięki temu, iż stworzyło nowy ideał wspólnoty, opierający się na dobrowolnej i świadomej partycypacji, idei solidarności oraz wspólnoty wartości. Taki model wspólnoty miał silny argument atrakcyjności - był bowiem stosunkiem otwartym, czym odróżniał się od większości wcześniej istniejących. Nie istniały żadne warunki wstępne - każdy mógł zostać chrześcijaninem, jeśli tylko wyraził chęć przystąpienia, czego wyrazem było nawrócenie. W wizji Klemensa wspólnota chrześcijańska jest wspólnotą wolności, w której uczestnictwo jest całkowicie dobrowolne, jest wartością samą w sobie oraz najwyższym dobrem.

\section{ARYSTOTELEJSKA WSPÓLNOTA DOSKONALĄCYCH SIĘ}

Wspólnota, tak samo jak jednostka, jest w ciągłej drodze ku doskonałości. Etapy na tej drodze obrazowo można przedstawić w formie szeregu łańcuchów.

Tab. 1. Stopnie doskonalenia się według Klemensa

\begin{tabular}{|l|l|l|}
\hline $\begin{array}{l}\text { Nawrócenie - } \\
\text { narodziny, dzieciństwo }\end{array}$ & $\begin{array}{l}\text { Wychowanie - } \\
\text { okres dojrzewania }\end{array}$ & $\begin{array}{l}\text { Nauczanie - } \\
\text { Dojrzałość }\end{array}$ \\
\hline \multicolumn{3}{|c|}{ Grupa } \\
\hline Niewolnicy, słudzy & Wierni słudzy & Gnostycy \\
\hline \multicolumn{3}{|c|}{ Stopień zaawansowania } \\
\hline Neofici & Szeregowi wierni & Wzory, niemal święci \\
\hline
\end{tabular}

19 F. Drączkowski, Kościót , s. 114. 


\begin{tabular}{|l|l|l|}
\hline \multicolumn{3}{|c|}{ Cnoty } \\
\hline Wiara & bojaźń, Prawo, gnoza & Agape, gnoza** \\
\hline \multicolumn{3}{|c|}{ Motyw działań } \\
\hline Kara lub nagroda & Posłuszeństwo & Agape \\
\hline
\end{tabular}

* Według Klemensa świętym można zostać nazwanym dopiero po śmierci (zob. IV 130,2).

** Gnoza występuje w dwóch miejscach łańcucha, ponieważ Klemens w różnych fragmentach odmiennie ją sytuuje.

Wspólnota chrześcijańska nieustannie dojrzewa do „synostwa bożego”, znajduje się w stanie „zbawczej przemiany” (VII 57,4). Każda jednostka pragnie zbliżyć się do ideału i zapewnić sobie wieczne szczęście. Nie ma natomiast szczęścia wspólnoty bez szczęścia każdego obywatela „Kościoła bożego”, które na ziemi osiągane jest jedynie cząstkowo, poprzez możliwość dążenia do tego nieprzemijalnego. Chrześcijanin rodzi się przez chrzest, wzrasta $\mathrm{w}$ procesie wychowania intelektualnego i etyczno-społecznego (postulowanego już przez Arystotelesa). Społecznego, gdyż cnota objawia się w czynie, a każdy czyn ma tutaj charakter świadectwa przynależności oraz staje się wzorem zachowań. Cnoty zaś rodzą cnoty i często tworzą szerokie sieci interakcji i wpływu. Stąd idea łańcuchów cnót. Cnoty połączone są ze sobą nierozerwalnymi więzami, są projekcją zasady mającej obowiązywać w skali całej wspólnoty. Tak jak jedynie koniunkcja wszystkich cnót daje pewne zbawienie, tak tylko $\mathrm{w}$ ramach wspólnoty, tj. $\mathrm{z}$ innymi ludźmi, niedoskonały $\mathrm{z}$ natury (bo skłonny do grzechu i słaby) człowiek może zapewnić sobie zbawienie.

\section{RÓWNOŚĆ, JEDNOŚĆ, BRATERSTWO}

Wspólnota projektowana przez Klemensa jest społecznością równych szans. Nie ma hierarchii w ścisłym tego słowa znaczeniu. Jedynym elementem różnicującym jednostki pozostające $\mathrm{w}$ obrębie grupy jest stopień zaawansowania $\mathrm{w}$ doskonaleniu cnót. Nie istnieje żadna „kasta gnostyków”. Najbardziej zaawansowani w doskonaleniu są „rezerwuarami cnót" dla całej wspólnoty. Tyle, że takim matrycowym chrześcijaninem może stać się każdy wierzący. Wszyscy ludzie zostali powołani do zba- 
wienia i do współtworzenia „Ciała Chrystusa”. Wyjątkowa, na tle epoki, była rola kobiet w wizji Aleksandryjczyka. Do pewnego stopnia, dla wielu współczesnych Klemensowi, musiało być szokiem przekonanie, iż nie ma cnót typowo męskich lub typowo kobiecych lub, że „kobieta różni się tylko jako samica, a nie jako człowiek” (IV 59,1-5). „W jakimś zakresie jest kobieta tym samym co mężczyzna, mianowicie w zakresie psychicznym, w tym że osiąga tę samą możliwość dzielności moralnej” (IV 60,1). $\mathrm{Z}$ czego wyciąga on wniosek, iż kobiety także powinny „mieć prawo do uprawiania filozofii na równi z mężczyznami”" ${ }^{20}$. Kobiety są zatem ważnymi członkami wspólnoty i nie należy twierdzić, że jako takie nie mają szans doskonalenia się i zbawienia. Każdy ma równe szanse zbawienia, nie każdy jednak w tym samym zakresie ze swojej korzysta, pomimo tego, iż jak zaznacza Klemens: „zachęca nas Pan zupełnie otwarcie do postępowania zgodnego z życiem gnostyka i do szukania prawdy czynem i słowem" (IV 35,1).

Idealna jedność jest cechą atrybutywną wspólnoty w wizji Klemensa. Cechę tę konstytuują wspólna wiara, Prawa, wspólne obawy i nadzieje, wspólne cele oraz łączący wszystko węzeł-agape. Słowem, nic nie powinno dzielić wierzących, gdyż zbyt wiele rzeczy ich łączy. Społeczność chrześcijan stanowi jedną wielką rodzinę, mającą ojca w niebie, który stanowi głowę wspólnoty i która widzi siebie jako grupę braci i sióstr.

Wspólnotę wyróżnia również wspólny habitus, który pozwala jej rozpoznawać samą siebie. On zaś kreowany jest przez Prawa oraz pisma nowotestamentalne i przez zbudowaną na nich etykę. Wspólność wartości i wynikających $\mathrm{z}$ nich cnót etycznych ma istotny wpływ na funkcjonowanie społeczności. Wspólna wiara jest wstępnym motywem homogenizacji wspólnoty, warunkiem początkowym. Wspólne podporządkowanie Prawu staje się czynnikiem prawdziwie spajającym szczególnie w sytuacjach poczucia zagrożenia z zewnątrz. Jest to jednak motyw sam w sobie niewystarczający. Dalej stoi obawa przed grzechem, tj. uchybieniem Prawu. Wspólnota zaczyna być wartością, gdyż powstaje obawa przed wyłącze-

${ }^{20}$ Aby jednak nie pójść za daleko, wypowiedzenie to kończy stwierdzeniem: „aczkolwiek pod każdym względem wyprzedzają oni [mężczyźni] kobiety” (IV 62,4). Klemens sam siebie ogranicza w swoim egalitarystycznym zapale, aby pozostać wiernym tezom swojego mistrza, św. Pawła (zob. 1 Kor 11,3). 
niem $\mathrm{z}$ niej. Strach przed odpadnięciem staje się motywem dyscyplinującym, wskazującym położenie jednostki wobec kosmosu spraw społeczności. Obawa ta wbudowana w jednostkę zapewnia po jakimś czasie silny mechanizm samodyscyplinujący. Dzięki niemu wspólnota nigdy nie staje się jawnie opresyjna wobec swoich członków. Wszystkie te czynniki służyć mają petryfikacji możliwie idealnej jedności grupy. Mechanizm samokontroli raz puszczony w ruch skutecznie zapobiegać ma przestępstwom oraz odstępstwom od normy grupowej. Wykształca on również instytucję skruchy, pojawiającą się w wyjątkowych przypadkach aberracji. Żal za grzechy jest formą społecznej higieny. Skrucha świadczy o świadomościowym charakterze wspólnoty, buduje stosunki jawne i wolne od niedomówień. Stąd jest kolejnym elementem, dzięki któremu jedność i pokój pozostają nienaruszone. Ważna jest również wspólna nadzieja. Nic tak nie cementuje grupy jak wizja wspólnej przyszłości, szczególnie tej świetlanej. Jest ona zatem silnym motywatorem wspólnych działań.

Ważnym elementem spajającym jest gnoza. Uwydatnia ona posiadanie czegoś na własność, co prowadzi do zagęszczenia intymności stosunków. Dobrze może to pokazać przywołana przez Klemensa Arystotelejska koncepcja przyjaźni. Wspólnota oparta na strachu i nadziei jest jakby odpowiednikiem przyjaźni kierującej się korzyścią związaną ze współpracą. Gnoza jest wstępem do Arystotelejskiej przyjaźni, polegającej na relacji opartej na umiłowaniu cnót, przyjaźni dla samej przyjaźni, niezależnej od czynników zewnętrznych. Takie relacje powinny dominować we wspólnocie chrześcijańskiej. Panować powinien stosunek równościowy, czyli jednocześnie stosunek: symetryczny (jeśli $\mathrm{X}$ jest przyjacielem $\mathrm{Y}$, to $\mathrm{Y}$ jest przyjacielem $\mathrm{X}$ ), przechodni (jeśli $\mathrm{X}$ jest przyjacielem $\mathrm{Y}$, a $\mathrm{Y}$ jest przyjacielem $\mathrm{Z}$. To $\mathrm{X}$ jest przyjacielem $\mathrm{Z}$ ) oraz zwrotny (X jest przyjacielem $\left.\mathrm{X}^{21}\right)$. Można stwierdzić, iż wspólnota Klemensa powinna być idealną wspólnotą przyjaciół, którzy cenią siebie ze względu na swe cnoty. Więź ta ma być bezinteresowna i autoteliczna. Wspólnota chrześcijańska zatem

${ }^{21}$ Por. przykazanie miłości (Mt 22,37-39) mówiące, iż należy miłować bliźniego w taki sam sposób jak siebie samego. Jeśli członka wspólnoty z innymi jednostkami mają łączyć więzy przyjaźni, to i sama jednostka musi traktować siebie jak swego przyjaciela. Jeżeli sama dla siebie jest wrogiem a innych powinna traktować jak samego siebie, to niemożliwa jest konstytucja jakiejkolwiek wspólnoty opartej na wzajemnej przyjaźni. 


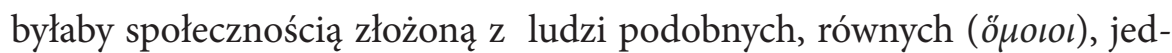
nakich co do wartości, solidarnych $\mathrm{z}$ racji wspólnoty urodzenia (chrzest jako powtórne narodzenie) i życia (habitus).

\section{AGAPE 1 JEJ KONSEKWENCJE}

Najważniejszą jednak rzeczą konstytuującą wspólnotę jest dla Klemensa agape. Można powiedzieć, iż jest ona zarówno wynikiem wszystkich poprzednio wymienionych cnót i czynników, jak również siłą sprawczą, powołującą je wszystkie do istnienia i pozwalającą im trwać i rozwijać się. Agape jest węzłem, który łączy człowieka z Bogiem, jak również człowieka z człowiekiem. Nie jest to jednak połączenie bezpośrednie. Można to zobrazować za pomocą trójkąta, którego górnym wierzchołkiem jest Bóg, a wierzchołkami przy podstawie są dwie jednostki. Im doskonalsza agape, tym wysokość trójkąta, a co za tym idzie odległość między jednostkami, mniejsza (zob. rys. 1). Stąd wniosek, iż im doskonalsza jest agape, im bliżej jednostka znajduje się Boga, tym bliżej jest drugiego człowieka. Klemens w tym miejscu powołuje się na zawarte w ewangelii św. Mateusza przykazanie miłości (Mt 22,37-39), które mówi o utożsamieniu swojego bliźniego (członka wspólnoty) ze sobą samym. Stanowi on drugie „ja” jednostki. W miłości w stosunku do brata natomiast zawarta jest miłość do Boga. Można powiedzieć, iż miłość bliźniego nie jest celem, lecz skutkiem agape boskiej.

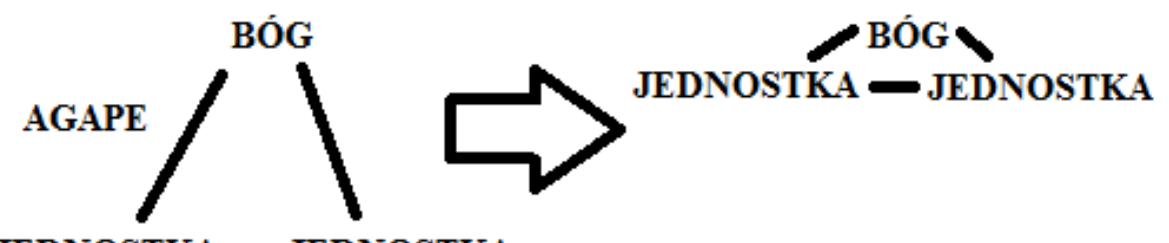

\section{JEDNOSTKA, , ,JEDNOSTKA}

Rys. 1. Skala mikro. Agape jest węzłem łączącym człowieka z Bogiem i poprzez niego z drugim człowiekiem („przez Chrystusa, w Chrystusie i z Chrystusem”). Im doskonalsza agape, tym wierny znajduje się bliżej Boga. Wysiłek ten zapewnia zmniejszanie dystansu między ludźmi.

Przede wszystkim agape „nie pozwala grzeszyć”, opanowując duszę do tego stopnia, że nie pozostaje miejsca na występek (IV 113,1). Tę właści- 
wość posiada ona z racji więzi z Bogiem, którą tworzy i podtrzymuje. Agape ma nie tylko właściwości hamujące, ale przede wszystkim wyzwalające. Dynamizuje ona wszelką działalność na rzecz Boga i wspólnoty, „jest ogniem i motorem wewnętrznym, źródłem niewyczerpanej dynamiki i niespożytej energii, jak akumulator, połączony z Boskim źródłem energii, czyli Boską agape"22. Z niej wynikają wszelkie cnoty etyczne egzystujące we wspólnocie:

Miłość daje się poznać w sposób wieloraki: albo jako łagodność, albo jako szlachetność, albo jako wytrwałość, albo jako wyzbycie się zawiści, fałszywej ambicji, czy nienawiści, czy jako zapomnienie uraz. [...] nie cierpi na żadne różnice i podziały, skłonna jest najbardziej do wspólnoty i do szczodrobliwości (II 87,2).

Agape jest tą bezinteresowną siłą, która łącząc wszystkich ludzi, tworzy relacje również z ludźmi spoza wspólnoty. Miłość rodzi sympatię i jest podstawą dla empatii. Wszyscy we wspólnocie są podobni, są bliźnimi, co implikuje relacje bliskości i intymności.

Dobrym przykładem ilustrującym pogląd Klemensa na relacje międzyludzkie jest małżeństwo. Tworzy ono pierwotną (chronologicznie i znaczeniowo) przestrzeń do kultywowania Praw i cnót, rozszerzanych następnie na całą wspólnotę. Związek kobiety i mężczyzny powinien być dobrowolny. Klemens zaleca, żeby kobieta „kochała nie z przymusu albo konieczności mężczyznę, który ją kocha” (II 137,4). Małżeństwo służy przede wszystkim prokreacji. Dzieci zaś potrzebne są do opieki nad rodzicami w okresie ich starości (zob. II 141,2) oraz jako dziedzice majątku. Klemens uważa, iż należy się żenić, „aby doprowadzić świat do maksymalnej doskonałości, w miarę naszych sił" (II 140,1). To enigmatyczne stwierdzenie, może oznaczać postulat dbałości o wychowanie i w ten sposób czynienie świata lepszym, poprzez „danie” mu wartościowych jednostek. „Niech dzieci nasze korzystają z wychowania w Chrystusie, niech się uczą, ile znaczy u Boga pokora, ile zdoła uzyskać u Boga czysta miłość, jak piękna i skuteczna jest bojaźń Boża, zbawienie niosąca tym wszystkim, którzy Nim żyją zbożnie, w czystości serca” (IV 108,3-5). Rodzina zatem ma funkcje socjalizacyjną. Reprodukuje ona wspólnotę, kreuje właściwą konstytucję etyczno-społeczną.

${ }^{22}$ F. Drączkowski, Kościót, s. 100. 
Małżonkowie powinni także wzajemnie się motywować w kroczeniu drogą cnoty. Miarą małżeńskiego szczęścia mają być cnoty (zob. IV 126,2). Ideałem związku kobiety i mężczyzny jest dla Klemensa małżeństwo ludzi filozofujących, które „wiedzie do jednomyślności zgodnej z rozumem. Ten zaś [rozum] wymaga od kobiety nie tyle dbałości o swój wygląd, ile pracy nad charakterem, mężczyznom zaś wzbrania traktowania żony jako miłośnice i za cel stawiać sobie nadużycie zmysłowe, natomiast zaleca uzyskać poprzez małżeństwo pomoc na całe życie i najwyższe umiarkowanie" (II 143,1). Żona jest pomocnicą męża (zob. IV 127,1; por. $\mathrm{Rdz} 2,18$ ), ma być mu we wszystkim posłuszna (zob. Kol 3,18-4,1 oraz 1 Kor 11,3), ale również jest tą, która poprzez cnotliwe życie może umacniać męża w dobroczynności i dawać przykład innym ludziom, co przyniesie jej szacunek, jak również zaszczyt mężowi.

Małżeństwo jest wspólnotą w mikroskali. Jest wypełnieniem miejsca między jednostką a społecznością, stanowi teren pierwotnych interakcji, przestrzeń gdzie cnota może zostać „wyćwiczona”. Wszystko, o czym wcześniej była mowa ma swoje miejsce $\mathrm{w}$ rodzinie. Jedność, harmonia, równość szans doskonalenia i miłość, przejawiające się na tym poziomie mają stanowić zaczyn dla wszelkich cnót i więzi w całej wspólnocie. W tym kontekście bardziej zrozumiałe wydają się surowe przepisy dotyczące cudzołóstwa (np. ukamienowanie). Nie bez powodu uważane jest ono za grzech przeciwko społeczności. Burzy bowiem jedność i zgodę, rodzi zawiść i kłótnie, niszczy trwałość rodziny, wprowadza kłamstwo i tajemniczość do relacji małżeńskiej. Słowem, uderza w podstawy wspólnoty, w same jej fundamenty. Jeśli na poziomie rodziny relacje nie są zgodne z postulowanym ideałem, jakże mogą one wystąpić na poziomie wspólnoty? Stąd też nakaz małżeństwa aż do śmierci. Rodzina ma spełniać swoje funkcje w ciągu całego życia jednostki, aż do jego końca, gdyż od niej zależy spójność, siła, żywotność i reprodukcja wspólnoty.

\section{WSPÓLNOTA-BÓG}

Można powiedzieć, iż wspólnota jest w pewien sposób Bogiem na ziemi. Jest czymś jednocześnie wewnętrznym i zewnętrznym wobec jednostki, która interioryzuje jej wartości, buduje w oparciu o nią swoją 
tożsamość, ma z innymi jej członkami wspólne nadzieje i obawy. Jednocześnie wspólnota jest w pewien sposób poza zasięgiem pełnego poznania. Każdy powinien dążyć do jedności z nią w sferze poznawczej, emocjonalnej i w sferze opinii. Społeczność czegoś od jednostki oczekuje. Dla wspólnoty należy mieć szacunek, uważać ją za istotną wartość, przestrzegać jej praw, podporządkowanie którym stanowi zaspokojenie potrzeby uznania przynależności. Strach przed wyłączeniem ze wspólnoty chroni grupę przed złem i jest silnym bodźcem dyscyplinującym jej członków. Jednostka powinna dążyć do pełnego utożsamienia się ze wspólnotą, do stanięcia „na gruncie pełnej jednomyślności” (IV, 132,1-2). Odpadnięcie od społeczności wiernych oznacza osamotnienie, zamknięcie drogi zbawienia, którym w pewien sposób staje się sama partycypacja. Im silniejsza zażyłość ze wspólnotą, jej wartościami, ideałami i członkami, tym blizzej jest się samego Boga, bo wspólnota jest substytutem i surogatem Boga na ziemi. Daje ona przestrzeń pozwalającą współdziałać „ku przywróceniu ludziom stanu prawdziwie doskonałej szlachetności i pokrewieństwa, aby włączyli się w „pełnię Chrystusa", co przez całą uprzednią zaprawę [życie zgodne z cnotami] dokonuje się w sposób całkowity" (IV 132,1-2). Wspólnota zatem daje możliwości większej grupie ludzi do osiągnięcia pełnego zjednoczenia z Chrystusem oraz całkowitej harmonii z początku czasów.

Projekt Klemensa, choć trudno uchwytny w pierwszym momencie, po dłuższej deliberacji okazuje się dosyć spójną, choć chaotycznie formalnie ujętą wizją wspólnoty. Społeczność ta ma bazować na wspólnym wszystkim członkom dążeniu do doskonałości, do zbliżenia się do Boga. Cechować ją powinna dobrowolność i świadomość partycypacji, wspólnota cnót, jedność, braterstwo oraz równość szans doskonalenia i zbawienia. Osiągnięte to być powinno za pomocą, łączących członków wspólnoty, więzi miłości i przyjaźni, które tworzyć mają postawy serdeczności, gościnności, wyrozumiałości i wytrwałości. Ma to być wspólnota „podobnych”, w której wszyscy wzajemnie umacniają się w dążeniu do „wyćwiczenia” cnót, gdzie każdy człowiek będzie bliźnim drugiego i gdzie zapanuje trwały pokój. Słowem, Klemens projektuje surogat wspólnoty niebiańskiej na ziemi. Docelowo ma to być społeczność bez struktury społecznej, bez kapłanów, zła, gdzie jedyną władzą będzie Bóg, który nie panuje, ale sam jest wspólnotą. Wszyscy bowiem jej członkowie są gnostykami, którzy są tak blisko Boga, iż niemalże zlali się z nim w jedną 
istotę, tak że nie ma między nimi znaczącej jakościowej różnicy. Skoro wszyscy są „w Bogu” są również w sobie nawzajem. Można powiedzieć, iż jest to ewolucja wstecz, gdyż mnogość wyspecjalizowanych segmentów tworzy jeden, nierozdzielny, ten z początku czasów (zob. rys. 2).

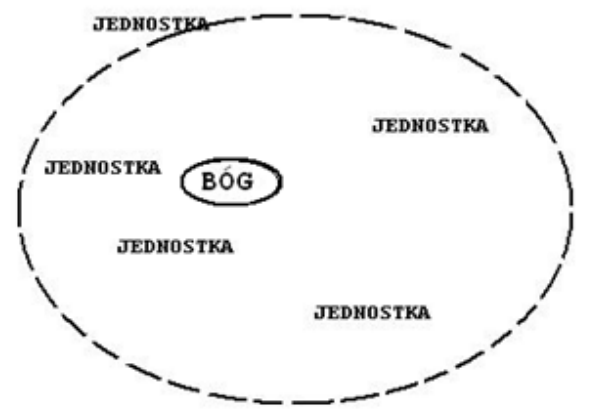

\section{WSPÓLNOTA}

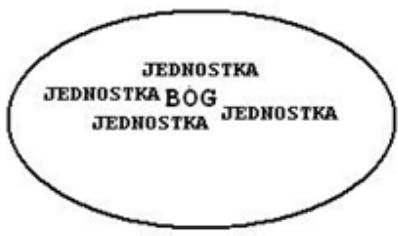

Rys. 2. Skala makro. Rysunek po lewej przedstawia wspólnotę w stanie dążenia do Boga. Jednostki znajdują się w różnej odległości od Boga, prezentują zróżnicowany poziom zaawansowania w cnocie. Występują wśród nich również „chrześcijanie z imienia”, będący na peryferiach wspólnoty (obcy), która nie ma jeszcze zwartości i jasno wytyczonych granic (linia przerywana). Rysunek po prawej ilustruje wspólnotę gnostyków, gdzie wspólnota jest skupiona blisko Boga, granice wewnętrzne prawie całkowicie zanikają, rysuje się za to jasno i wyraźnie granica zewnętrzna wspólnoty.

\section{KONKLUZJA: ZNACZENIE WIZJI KLEMENSA}

Wizja wspólnoty przedstawiona w Kobiercach ma charakter silnie utopijny i idealistyczny. Pomimo wyraźnego praktycznego zacięcia jest ona koncepcją filozoficzną, rzeczywistość społeczna zaś okrutnie ją zweryfikowała. Ważniejsze jest jednak, iż nauki Klemensa, pokazują pewien sposób myślenia o wspólnocie, który w jakimś zakresie przetrwał do współczesności. Jednym z zagadnień podejmowanych przez nowoczesnych myślicieli jest tęsknota za pierwotną wspólnotą ludzką (Rousseau i in.). W obecnych czasach jesteśmy świadkami słabnięcia więzi między ludźmi, zaś erozja wspólnoty (sąsiedzkiej, religijnej, politycznej) stała się pewnych signum współczesności. Jak widać, Klemensowi przyświecała podobna myśl. W jego przypadku jednak, tęsknota odnosiła się do pierwotnej jedności wspólnoty (,jako było na początku, teraz i zawsze”). Wydaje się, że Klemens zakładał, iż wspólnota docelowo obejmie całą ludzkość, o czym 
świadczy choćby włączanie barbarzyńców jako potencjalnych członków wspólnoty. Widać jednak wyraźnie, że jego projekt był silnie zakorzeniony w mikrokosmosie wczesnochrześcijańskich gmin odseparowanych od siebie geograficznie - jego wizja konstruuje relacje międzyludzkie na zasadach współżycia niewielkiej gminy i w samym swym charakterze jest elitarna.

Kolejną tęsknotą współczesności jest stałość i pewność. W świecie szybkich i dynamicznych zmian dominuje mentalność „krótkiego trwania”23. Współczesnym społeczeństwom brakuje jasno wytyczonego celu a głównym rodzajem ruchu, który w ich ramach się odbywa, jest dryfowanie. Relacje międzyludzkie tracą na jakości i trwałości. Jak wskazuje Zygmunt Bauman „niepewne warunki społeczno-gospodarcze przyzwyczajają ludzi (często drogą bolesnych doświadczeń), by traktowali świat jak pojemnik pełen przedmiotów jednorazowego użytku. By traktowali tak cały świat - w tym także swoich bliźnich"24. Świat społeczny wydaje się być pozbawiony realnej i sensownej teleologii. Zapomina się o wartościach wspólnotowych - na co wskazuje Klemens podkreślając, iż to właśnie w realnej (nie nominalnej) wspólnocie jednostka jest w stanie osiągnąć spełnienie, które w chrześcijańskiej wizji równa się zbawieniu. Oryginalność myśli Klemensa polega przede wszystkim na dowartościowaniu elementu wspólnotowego - to nie wyizolowana, medytująca, poszcząca, pobożna jednostka jest ideałem, lecz ten kto kultywuje cnoty w trakcie interakcji z innymi. Cnota kultywowana poza społecznością wiernych jest w większości wypadków jałowa - to wspólnota wiernych zbliża do Boga i poprzez boską agape zbliża do innych ludzi. Inni, w wizji Klemensa, są niezbędni do osiągnięcia zbawienia, bowiem cnoty, które do niego prowadzą, są cnotami stricte społecznymi, tj. prawdziwie objawiają się jedynie $\mathrm{w}$ codziennym działaniu, w codziennych interakcjach $\mathrm{z}$ innymi ludźmi. Można nawet powiedzieć, że to wspólnota czyni jednostkę człowiekiem, a tylko człowiek może dostąpić zbawienia.

Jak chciałem pokazać, Klemens może być zaliczony w poczet prekursorów chrześcijańskiej myśli społecznej, która wcale nie zaczęła się wraz ze św. Augustynem. Oczywiście ten ostatni miał większy wpływ

${ }^{23}$ Z. Bauman, Płynna nowoczesność, tłum. T. Kunz, Kraków 2006, s. 228.

${ }^{24}$ Tamże, s. 251. 
na ukształtowanie się teorii i praktyki Kościoła Katolickiego, jednak w projekcie Klemensa możemy odszukać wiele oryginalnych motywów, np. dotyczących roli kobiet. Rekonstrukcja jego wizji wspólnoty pozwala zobaczyć w jakich kategoriach była ona ujmowana i na jakich wartościach wczesne chrześcijaństwo chciało konstytuować swoją nieskrystalizowaną jeszcze tożsamość. Ciekawa w tym kontekście jest również rola pogańskiej filozofii, która, co wyraźnie widać w Kobiercach, stała się rezerwuarem idei, na bazie których wczesny Kościół budował swoją teologię.

Streszczenie. Artykuł przedstawia wizję idealnej wspólnoty chrześcijańskiej wyłaniającą się z Kobierców Klemensa Aleksandryjskiego, który opisuje postać gnostyka, idealnego chrześcijanina oraz cnoty go charakteryzujące, w tym najważniejszą z nich, agape. Na tej podstawie $\mathrm{w}$ artykule zrekonstruowana została wizja idealnej wspólnoty. Klemens podkreśla istotność wspólnoty dla jednostkowego zbawienia oraz pokazuje, że droga do niego prowadzi poprzez innych ludzi, ponieważ tylko we wspólnocie cnoty mogą być praktykowane. Artykuł ukazuje oryginalność Klemensa Aleksandryjskiego jako jednego z prekursorów chrześcijańskiej myśli społecznej.

Słowa kluczowe: chrześcijańska myśl społeczna: wspólnota: agape: gnostyk.

Abstract. The ideal Christian community according to the Stromata by Clement of Alexandria. The article is presenting the vision of ideal Christian community emerging from the Stromata by Clement of Alexandria, who depicts the figure of gnostic, ideal Christian and virtues by which he is characterized, including that of the most importance, agape. On this basis in the article the vision of ideal community was reconstructed. Clement highlights the importance of community for individual salvation and shows that the way toward it leads through other people, because only in the community the virtues can be practised. The article lay out the originality of Clement of Alexandria as one of the forefathers of the Christian social thought.

Keywords: Christian social thought; community; agape; gnostic.

\section{BIBLIOGRAFIA}

Arystoteles, Dzieła wszystkie, tłum. D. Gromska, L. Regner, W. Wróblewski,V, Warszawa 2002.

Bauman Z., Płynna nowoczesność, tłum. T. Kunz, Kraków 2006.

Brown P., Ciało i społeczeństwo, tłum. I. Kania, Kraków 2006, s. 139-156.

Chadwick H., Myśl wczesnochrześcijańska a tradycja klasyczna, tłum. P. Siejkowski, Poznań 2000, s. 41-63. 
Diogenes Laertios, Żywoty i poglądy słynnych filozofów, tłum. I. Krońska, Warszawa 2004, VII,1-160, s. 369-442.

Drączkowski F., Kościót-Agape według Klemensa Aleksandryjskiego, Lublin 1996, s. 35-68, 91-128.

Klemens Aleksandryjski, Kobierce, tłum. J. Niemirska-Pliszczyńska, I-II, Warszawa 1994.

Niemirska-Pliszczyńska J., Wstęp, w: Klemens Aleksandryjski, Kobierce, t. I, Warszawa 1994.

Osborn E., The Philosophy of Clement of Alexandria, Cambridge 1957, s. 127-145, 158-167.

Platon, Sofista w: tenże, Sofista; Polityk, tłum. W. Witwicki, Kęty 2002.

Reale G., Historia filozofii starożytnej, tłum. E. Zieliński, III, Lublin 1999, s. $394-436$. 